\title{
ЕЛІТАРНА МОВНА ОСОБИСТІСТЬ У СИНТАКСИЧНІЙ РЕПРЕЗЕНТАЦІЇ ЩОДЕННИКОВОГО ДИСКУРСУ
}

\begin{abstract}
Ігнатьєва С. С. Елітарна мовна особистість у синтаксичній репрезентації щоденникового дискурсу.

У статті запропоновано визначення мовної особистості елітарного типу, сформовану в межах щоденникового дискурсу, систематизовано мовні параметри та визначено перспективи ії синтаксичного моделювання. У вибудуваній моделі виокремлено внутрішній комунікативно-прагматичний потенціал синтаксичної конструкції, наголошено на його важливості у формуванні щоденникового тексту. Виявлено інфосегменти, що значно розширюють межі інформаційного поля.

Ключові слова: елітарна мовна особистість, синтаксичне моделювання, комунікативно-прагматичний потенціал, щоденниковий дискурс
\end{abstract}

Игнатьева С. Е. Элитарная языковая личность в синтаксической репрезентации дневникового дискурса

В статье предложено определение языковой личности элитарного типа, сформированной в рамках дневникового дискурса, систематизированы ее языковые параметры та очерчены перспективы синтаксического моделирования. В построенной модели выделен внутренний коммуникативно-прагматический потенциал синтаксической конструкции, определена его важность в формировании дневникового текста. Выявлены инфосегменты, которые значительно расширяют границы дневникового информационного поля.

Ключевые слова: элитарная языковая личность, синтаксическое моделирование, коммуникативно-прагматический потенциал, дневниковый дискурс.

Ignatieva S. Ye. Elite language personality in the syntactic representation of the diary discourse

The article concerns some notification of the language personality formed in the frames of the diary discourse, there were also systemized its linguistic parameters and pointed out perspectives of the syntaxes modeling. The build up model is stressed with its inner communicative-pragmatic potential of the syntax construction and its necessity. In the constructed model is highlighted internal communicative-pragmatic potential syntactic structure is determined by its importance in the formation of the diary text. Infosegmenty revealed that significantly expand the boundaries of the diary of the information field.

Key words: elite linguistic personality, syntax modeling, communicative and pragmatic potential, дневниковый discourse. 
У науковій парадигмі кінця XX - початку XXI століття домінуюче місце належить антропоцентричній лінгвістиці як одній iз найдинамічніших напрямів сучасної науки про мову. Антропоцентричний напрямок науки і тенденцій прагматичної реалізації теоретичних досліджень безперечна. Лінгвістика $є$ однією 3 найбільш гуманістично орієнтованих дисциплін, що визначає формування i розвиток різних напрямків, в тому числі теорії мовної особистості. На сучасному етапі лінгвістики теорія мовної особистості розвивається досить активно. Інтерес до особистісного аспекту вивчення мови істотно підвищився в останні роки не тільки в лінгвістиці, а й у психології, філософії, соціології, лінгводидактиці. Проблеми теорії особистості так чи інакше пов'язані з мовною поведінкою людини, оскільки людина реалізує себе не тільки у вчинках, а насамперед у мові. Як зауважує О. Сербенська, відбувається методологічне зрушення - заміна базисної парадигматики в сучасному мовознавстві, перехід від лінгвістики «іманентної» 3 їі домінантою на вивчення мови «у самій собі й для себе», від вивчення мови, коли пріоритетною вважалася граматика, до лінгвістики антропологічної, яка потрактовує мову як конститутивну особливість людини, оскільки людина є людиною тільки завдяки мові, розглядає мову в тісному зв'язку зі свідомістю, мисленням, духовністю, практичною діяльністю, виходячи 3 розуміння людини як єдності фізичного й духовного, природного й соціального, успадкованого й за життя набутого [10, с. 120].

Розглянемо щоденниковий дискурс 3 огляду синтаксичної організації моделі мовної особистості зразкового (елітарного) типу. Така мовна особистість зберігає в своїй генетичній пам'яті вербально фіксовані знання зі сфери національного спадку, включаючи різного роду міфологеми, обрядові формули, традиційні стереотипи тощо. Склад синтаксичних конструкцій, що є базовими в мові того чи того суб'єкта, слугують особливим демонстраційним екраном, що відображає інтелектуальний рівень і емоційний стан особистості їхньго автора (адресанта). Спектр пріоритетних мовних конструкцій, які властиві для будь-якої особистості є індивідуальним, віддзеркалює особливості внутрішньої організації свідомості, індивідуальну картину світу, а способи репрезентації особистісних потенціалів засвідчує відношення до навколишнього світу.

Наша мета - дослідити мовну особистість елітарного типу (EMO), сформовану в межах щоденникового дискурсу, систематизувати іiі мовні параметри і визначити перспективи для синтаксичного моделювання. У вибудуваній моделі елітарної мовної ๑) С. Є. Ігнатьєва, 2013. 
особистості виокремити внутрішній комунікативно-прагматичний потенціал синтаксичної конструкції, визначити його роль у формування щоденникового тексту.

Предметом аналізу мовної особистості, репрезентованої у щоденниковому дискурсі, визначається елітарна мовна особистість. У сучасних комунікативних умовах цей тип особистості ще не знайшов належного висвітлення. 3 іншого боку, необхідність у формуванні мовного обличчя діариста безсумнівна.

Визначення ЕМО необхідно пов'язувати 3 іï інтелектуальними характеристиками, які найповніше виявляються в мові. Мовлення українських діаристів визначається насамперед автокомунікативністю, чіткістю у визначенні своєї позиції; миттєвою реакцією на події, які $\epsilon$ значеннєвими для власного «Я», а також ненав'язливе просвітительство.

Моделюючи мовну особистість елітарного типу, спираємось на теоретичні засади, зроблені В.І.Карасиком та О.О.Дмитрієвою. ЕМО можна розглядати як «модельну особистість» - еталонну, ідеальну, яка варта наслідування. Розглядаючи особистість «як складну відкриту систему, що розвивається», не можна недооцінювати внутрішнього їі розвитку під впливом зовнішніх чинників, передусім тих, що продукуються національно-культурним середовищем [8, с. 13]. Ш. Баллі, розглядає мову не просто як інструмент спілкування, а символічну систему соціальної взаємодії особистостей. Швейцарський лінгвіст багато в чому випередив пізніші ідеї соціолінгвістики i лінгвістичної прагматики, зокрема глибоко обгрунтував положення про те, що найважливіша одиниця спілкування - речення - це єдність диктуму, що виражає судження особи про певний факт об'єктивної дійсності (або суб'єктивних відчуттів, вірувань, емоцій тощо, які сприймаються як об'єктивність) і модусу, який виражає різноманітні відтінки почуттів або волі [1, с. 44-45]. ЕМО має свої ідеальні цінності, свій метод їхнього відбору, що залежить від певного типу іï мовленнєвої культури та іiі індивідуальних особливостей.

Важливою рисою зразкової мовної особистості в щоденниковому дискурсі $є$ вживання вставних елементів - того спектру синтаксичних явищ, які кваліфікують як вставні (детальний аналіз таких синтаксичних явищ представлений у працях I. І. Щебольової, А. I. Анікіна, А. Ф. Прияткіної, Н. С. Валгіної, І. П. Распопова, А. М. Ломова, П. А. Леканта), вітчизняних мовознавців Д. Х. Баранника, А. В. Висоцького, А. П. Загнітка, Д. І. Жуженка, Л. О. Кадомцевої, М. У. Каранської, М. А. Карпенко та інших увчених. На нашу думку, 
особливості вставних конструкцій сприяють створенню паралельного плану оповіді, слугують додатковою „інформаційною сіткою”, яка, накладаючись на основной текст, формує історико-культурну атмосферу. Тому вставні конструкції, які є семантико-комунікативно значеннєвими в межах нашого дослідження вважаємо за можливе позначити інфосегментами. У щоденниковому дискурсі нами виокремлено такі інфосегменти:

•інфосегмент-топос. Його завдання - виявити співвідношення позначуваного факту, явища, теми, ідеї 3 конкретними історикогеографічними реаліями, які визначаються географічними реаліями: Запоріжжя (з боку Мелітополя). Опівдні [3, с. 138]; Зелений тунель Паркової алеї (як їхати знизу в напрямі Аскольдової), а потім буяння вподовж вулиці розквітлих каштанів - це образ весняного Києва [5, с. 57]; А в тому напрямкові, куди йдемо ми (на захід), теж досить часто повстають низки італійських обшарпаних машин, в яких сидять такі ж обшарпані закутані вояки [7, с. 278]; Йосип Гірняк, який був $i$ вислизнув зі Львова і жив у Криниці (передмістя Салатва), дістав рімучий наказ негайно повернути до театру [7, с. 352];

•інфосегмент-ім'я містить точну інформацію про автора будьякого художнього твору, про людей з якими довелося спілкуватися: Образ Сергія (Сови). Ві найменший в родині $i$ звик, щуо на нього дивляться як на хлопчака [3, с. 134]; У кімнатах повний армійський порядок. Надто у «хоромі», де сплю: книги на етажериі (найнеобхідіші - Шевченко, Біблія, Грихір Тютюнник і Шолохов, Толстой і Достоєвський) лежать, стосиком акуратним складені... [2, с. 594]; Історію й суспільствознавство викладаю, і моїм головним консультантом-наставником Дмитро Устимович Манець (колишній учитель мій Бреусівської иколи) [2, с. 623];

•інфосегмент-факт містить не обов'язкову безпосередньо в цьому висловлюванні, але які поглиблюють сутність ситуації, про яку пише наратор: Щойно повернувся від Михайла Шевченка (разом ӥхали 3 роботи, забалакалися, і він запросив додому) [2, с. 645]; Далі майже вся дорога захаращена поваленими деревами і недалечко від того повороту на гірську дорогу, де я біг з малим у нестерпному сяйві бомб (ми тоді на цій дорозі були тільки вдвох, останні з цісї навали людської, щцо вмить злякано розпорошилась десь по кущах і закутках), - недалечко від того місия розбризкано, як трісочки, дошки паркану $i$ за купою упалих дерев зяють ями, бовваніють довколишні їхні огреблення 3 перепоротої, перекімшеної, аж наче закипілої землі [7, с. 300];

•каузальный інфосегмент пояснює факт, визначає причину

๑) С. Є. Ігнатьєва, 2013. 
виникнення події, про яку повідомляє автор, співвідносить їх із соціально-історичними умовами, які визначають їхню появу чи розвиток: Виявляється, я був у числі смертників, украӥнських камікадзе 1941-го року. Як свідчить Дмитро Білоус, щуо був теж студбатівием (хоч на фронт, видно, ми відправлялись у різних ешелонах) зустрічати їхній ешелон тоді прибув із Ставки генерал Кривонос; він тоді відверто сказав, щзо нам, харківським студентам, відведена саме така роль; хай і ціною власного життя, маємо перепинити рух ворожих танків, прикрити Київ, бо інших військ тут нема [5, с. 465];

•інфосегмент-персоналія - залучення цитати, своєрідне аргументаційне посилання на авторитет, яке підкріплене достовірність чи теоретичну можливість викладеного: Маємо прагнути писати про те, як знайшов істину, а як ї̈ шукаєщ; тобто анатомувати «энергию заблуждения» (вислів Толстого) [2, с. 582].

3 огляду на виокремлені інфосегменти, які $\epsilon$ семантикокомунікативно значеннєвими в межах нашого дослідження, стверджуємо, що принципово важливим для реципієнта $є$ правильне тлумачення тих мовних засобів, які вживає адресант щоденникового тексту, точне розуміння адресатом інформації, зафіксованої в ньому.

Це сприяє формуванню спектра інфосегментів, які уможливлюють регулювання саме зовнішньомовного аспекту мовлення, уплив на адекватність «перемикання кодів», уживаючи слова, висловлювання, які знаходяться в різних мовних чи культурных сегментах. Можна говорити про окремі типи лексичних інфосегментів (лексичних у тому розумінні, що вони співвідносні з окремими лексемами):

•експресивний інфосегмент - ставлення до предмета, явища, події: I малий, також на щастя, поправився, - не кашляє, добре їсть, добре спить, добрий настрій має, добре виглядає (тьфу! тьфу! тьфу!) $i$ помітно, просто на очах, росте [7, с. 438]; Одержав останніми днями теж чимало листів, зокрема від Людмили. Вона опинилась в Кітцінгені на Майні, праџює на фабрищі бочок (!), просить писати [7, с. 433];

-семантичний інфосегмент - банальне тлумачення будь-якого слова: Горобецьь, щзо заправляв від’̈̈дом, уже вантажив речі на машину (тягарову), на яку зверху напнули халабуду [7, с. 276];

•етимологічний інфосегмент, який пропонує етимологію слова, співвідносить його з сучасними мовними одиницями: Колись нас сюди швейцар (вратнік) навіть на поріг не пустив би [3, с. 130]; На Ващлавському намєсті (майдан) вивішена мапа Радянського Союзу, ілюстрована [3, с. 132];

•інфосегмент-уточнення, у якому інформація щодо події 
поглиблюється за рахунок вставного словосполучення: Днями нам статут (фундаторів відбудови Золотоверхого) вже зареєстровано, мене обрано президентом цзього світлого діла [5, с. 464];

- інфосегмент-переклад дає тлумачення слів якогось соціального жаргону або територіального діалекту або який пропонує іншомовний аналог: Трактористи лишають в полі балалайки (огріхи) [3, с. 127].

Отже, в українському щоденниковому дискурсі інфосегменти допомагають мовцеві розширити межі проблеми, що обговорюється, вписати тему свого запису в загальнокультурний контекст, реалізувати комунікативну категорію інформативності в іiі додатковому значенні. Дотримуються також межі соціально-етичної категорії ввічливості щодо адресата, оскільки за формою реалізації вставні компоненти слугують своєрідними маркерами-відсиланнями до конкретних фактів, які допомагають мовцеві пригадати факт без зайвого дидактизму. Таке толерантне ставлення до адресата сприяє формуванню атмосфери конгруентності, діалогічності, що є виявом вищої мовленнєвої майстерності.

Однією 3 синтаксичних структур, спроможних висловлювати кілька думок у простому реченні, є просте ускладнене речення. У щоденниковому дискурсі виразно простежується вживання цього синтаксичного засобу. Як елементи ускладнення простого речення адресант активно вживає вставні та вставлені конструкціі, які, на думку професора А. Г. Руднєва, «оживляють мовлення, насичують його відношенням адресанта до того, що він висловлює.., вони сприяють такій організації мовлення, яка б найбільш ефективно впливала на співбесідника в потрібному напрямку, щоб забезпечила найбільш правильне розуміння смислу сказаного» [9, с. 216].

Український щоденниковий дискурс містить критичний аналіз подій, явищ, а також аналіз творчості адресанта. Звичайно, складно висловити свою думку однозначно, тому адресант вживає суб'єктивну ірреальну модальність висловлювання, оформляючи іiі за допомогою вставних модальних слів можливо, може, мабуть, очевидно. Наприклад: Гоголь заповідав щзоб тіло його було перевезено у Василівку, на Україну... Може, колись і треба иче зробити? [4, с. 428]; Звичайні трудові квартали передмістя. Дітвора весело перегукується. Стара жінка сидить на балконі: тужлива, сумна як образ людського згасання. Сумно й мені. Це та Болгарія, щзо ї̈, мабуть, бачу востаннє [4, с. 430]; Очевидно, масштабність злодіянь, нечувана кількість жертв мали в собі й певну магічну силу, принаймні обивателя все ие могло не приголомшити [4, с. 492]. Важливим, на (ㄷ. С. Є. Ігнатьєва, 2013. 
нашу думку, є авторське наповнення щоденникового тексту теплим ставленням до природи. Адресант персоніфікує живу та неживу природу й навчає цьому адресата. Задля переконання оповідач вживає вставні модальні слова, тим самим ніби запрошує адресата до спільних роздумів, міркувань. Наприклад: За вікном - липнева краса хлібів. Смагляві пани серед березових ніжинських перелісків. I так це гармонійно поєдналось: прохолода гаӥв , $i$ сонячність лану, $і$ смужка води щзо проблискує поміж рогозою у вибалку, де колись, мабуть, текла чималенька річка [4, с. 153]; Гола весна початку квітня - вона чудова! Їду з Харкова, ранок сонячний, трохи млистий. Зелені щее нема, $і$ голі дерева, і трави торішні - випрані, вилинялі за зиму а по степу усі видолинки поналивані чистою - після дощів - водою. Це вже справжня, видно, весна бо так тепло $i$ грім - синій грім! - уже гримів... [3, с. 213]; Бліда міська заграва, підсвічуючи хмари з боку Києва, ще мовби більще відтіняє правічну моторошну глибінь задніпровського мороку, де в титанічній борні клекочуть стихї $i$ звідки аж сюди долітають суворі вітри - невідомо, щуо вони навіють: нові мряки чи вже, може, сніги? [3, с. 230]; Мабуть, немас нічого величнішого, як місяцьь над степом вечірнім. Десь у Фергані, де млисто, м'яко, де й гори напрти місяця зі своїми химерними лініями [4, с. 35]. Окремі роздуми адресант передає адресату з сумнівом, і тоді вставні слова, як правило, приєднують вставну конструкцію: Понуре шлакоблокове місто в степу. Низькохмарне холодне небо розпласталось над ним. Караганда. Може, від таких ночей, від таких замріяних шелестінь та дзюркоту ариків люди кочовищ колись тут ставали мудрецями [4, с. 92]. Вставні синтагми в окремих випадках вживаються наратором як сполучники сурядності: $У$ справжньому мистецтві завжди існує тайна чи ї̈ елемент. I, мабуть, цчим воно найпривабливіме [4, с. 74].

Український щоденниковий дискурс містить вставні синтагми емоційного характеру. Такі мовленнєві конструкції надають емоційну оцінку побаченому, почутому, уможливлюють адресанту висловити свої почуття, переживання: Постріли, на мцастя, не пролунали, кров не полилась, тихо було, то ангел надї пролетів над їхнім чудовим краєм, над ними всіма, мовби богонатхненними... [4, с. 34]; В итучного інтелекту будуть інші органи (які саме, покаже майбутнє), але хвороб інтелекту, на жсаль, не уникнемо... Людині притаманна творчість. Проте по-різному $і$ з різними полярними цілями творять... На жсаль. $А$ тому на перешкоді підводне каміння будь-який розвинений інтелект спроможний до самопізнання [2, с. 269]. Деякі думки автор передає 
читачеві з сумнівом, тоді вставні слова, як правило, приєднують вставну конструкцію: А для Бога - поки щио складається в мене враження таке місия на землі не зоставили... [2, с. 511]. Вставна лексема правда вказує на високий ступінь упевненості адресанта,: друга частина речення приєднується за допомогою допустового сполучника хоч: Злюся, правда, на себе: $і$ який же я, хоч $і$ стріляний горобець, а все одно довірливий занадто ... [2, с. 509]. На високий ступінь упевненості адресанта вказує вставне слово звісно. Воно протиставляється попередньому й приєднується за допомогою протиставного сполучника однак: Пообічяли, шуо в найближчому номері «Дніпра» надрукують кілька мойх оповідань. Я, звісно, почувався на сьомому небі, $і$ кілька днів для мене, мабуть, із усіх людей планети Земля найяскравіше сонце сяяло; $і$ не лише у небі, а й у душі. Однак... тільки моя нога ступила на територію київського провідницького резерву...[2, с. 504].

Проте кожен мовець формується у просторі, що створюється мовою як явищем неіндивідуальним. Внутрішній комунікативнопрагматичний потенціал тієї чи тієї синтаксичної конструкції виявляється пов’язаним з будь-якою психічною ознакою, властивою кожному мовцеві. Можна стверджувати, що кожен мовець, маючи схожі риси характеру, вдачі, особливості світосприйняття чи поведінки, однаково синтаксично будують мову, користуються схожим спектром пріоритетних синтаксичних конструкцій. Тобто закономірна гіпотеза про універсальність функціонування будь-яких синтаксичних конструкцій у мові різних комунікантів.

Аналіз уживаних автором простих речень у щоденниковому тексті засвідчують його емфатичні переваги. Активно структуру простого речення визначають питання, які адресант ставить насамперед перед собою, формуючи таким чином атмосферу автодіалогу. Питання адресант формулює коротко i виразно, як 3 позиції структурної організації так і з позиції вживаної лексики. Це сприяє більш логічно структурувати щоденниковий запис, представити власну манеру викладу матеріалу, закцентувати увагу адресата на найбільш важливих аспектах проблеми, які на певний момент часу є для нього більш значеннєвими. Наприклад: $H y$ добре. Хай буде так. Я майстер. Свойми творами я дарую вам радість. А ичо ви мені подарували? Я поставив перед собою одну мету: возвеличення народу засобами мистецтвва. Моя мета - радість народу, який ви очолюєте. Чого жс я мушу боятися вас? Нашьо ви возненавиділи мене? Що ви мені дали? Чи дали за чверть століття хоч одну пораду, підказали цио, натхнули, уважсили?

(C) С. Є. Ігнатьєва, 2013. 
Підтримали, збагатили мої почуття, допомогли відпочинути бодай? Спитав хто з вас, що мені треба, чого бракує для творчості? Hi [6, с. 323]; $\epsilon$ відчуття завершеної великої й чесної праиі. А що скажуть люди, читачі? А надто ж ті, що міжк читачами і автором? Невже готують $і$ цій тернисту дорогу?.. [4, с. 376]; Читаю цього новоархангельського автора і думаю: невже він чимось так внутрішньо завинив, щео тепер своїми писаннями тільки й доводить людові свою лояльність? Уперто, натужно, не помічаючи, як стає іноді навіть смішним у иих нікому не потрібних стараннях... Так і хочеться сказати: «Отямся, озирнись». Довкола люди як люди, а ти... Чим ти аж так переляканий? Чи просто діс інерція? [4, с. 378].

Отже, питальні речення в щоденниковому дискурсі адресуються співрозмовникові, яким є адресант. Саме від себе він очікує відповідь, оскільки саме він слугує джерелом викладеної інформації. Окличні речення, побудовані за зразком простого речення неускладненої структури, сприяють формуванню тих же комунікативних параметрів: автокомунікація мовлення і чіткість визначення авторської позиції. Наприклад: Коли б можна було б Іронію $i$ Жалість зробити суддями $i$ свідками злочинств епохи!.. Господи, як мені остогидли за чверть століття слова - «український наиіоналізм!» [6, с. 237]. Це була ювілейна буря! Повно гостей $і$ в Києві, і наступного дня в Кончі. Такого й не сподівався! [5, с. 464].

Поєднання питальних і окличних речень в одному текстовому уривку створює тональність особливої емоційної напруги. Такі мовні конструкції можливі лише в разі глибокої особистої зацікавленості автора в розв'язанні проблеми, стосовно якої від дискутує із собою або навпаки залучає до проблеми, що його хвилює інших реципієнтів, які, можливо, у майбутньому, зацікавляться цією проблемою або викличе в них співчуття або, і це найважливіше, розв'яже свою внутрішню напругу, розкриє свій духовний світ. Наприклад: Химерно! Ти, Аркадію, пережив стільки лиха й загроз, перейшов уже такий страдницький, справді хресний шлях, добувся ген-ген куди, сподіваючись порятунку, - невже отут, на чужині, десь під Берліном, доведеться загинути? Не віриться. Для чого ж мене доля зберегла досі? Краще було б загинути одразу. Але... знаю, знаю. $С$ приреченість, є в мене мій Дажбог - і тут нічогісінько не вдієш, крім одного: бути мужнім, енергійним і н губитись хоч би що [7, с. 439]; У вівторок 30-го промовляв Гітлер до нім. народу. I щзо ж? Нічогісінько! Крім старих, затертих, мітингово-істеричних фраз - 
нічогісінько нового, жодного конкретнішого, щзо збудив би ци загрунтував якусь надію, моменту. Йому нема чого сказати. «Король», бачу, справді голий. Банкрот! [7, с. 439]; Маса втікачів йде пішки з дітьми зі стариками, часто сяк-так зодягнені, в чому встигли вискочити. І це серед зими! Жах! Не розумію, чому це все могло статися? Де ж⿻ розвідка? Де ж німецька хвальна передбачливість (самі ж трубили про сподіваний наступ зі сходу). I педантична організованість? Сталін кінчає так, як Гітлер починав. От діалектика! Чи ие виключна нездарність нім. командування на цъьому фронті? Чи, може, чергова зрада? Так щзось виглядає. Припустити інше - це припустити справді надзвичайну могутність, непереможність большевищької сили. Тоді - кінець. [7, с. 438].

Питально-відповідна форма викладу уможливлює не лише автодіалог. Така форма створює ситуацію непрямого цитування думки наратора. Реципієнт через роки, десятиріччя і навіть сторіччя може виразно простежити за думкою наратора, чітко визначити його життєву позицію: Господи, ну нащзо він кинув мене, нащзо одиурався? Невже я такий небезпечний? Нащо ж мені жити?... Що зі мною? Хто прокляв мене? За щзо? Невже такий я став лихий чи не інтересний, чи підозрілий? Нащуо ж я жив на світі? Нащзо мене дурили талантом моїм, умінням, любов'ю до людей? Почну боятися себе. Чи що мені робити тут у Москві на самоті? Кричу! [6, с. 320].

Літературний щоденниковий текст засвідчує високий рівень освіченості його творця - комуніканта-продуцента, вказує на письменницьке інтелектуальне оточення, окреслює коло визначних інтелектуально обдарованих особистостей - письменників, художників, музикантів, політиків, журналістів, священників, фіксує факти та розкриває характер спілкування 3 ними, що, безперечно, упливає на його саморозвиток.

Отже, синтаксична модель елітарної мовної особистості становить важливий засіб формування щоденникового тексту. Вона уможливлює виокремлення актуальних прагматичних напрямків функціонування концепції синтаксичної характеристики мовної особистості, які вирізняються особливою значущістю вияву особистості в різних формах. Активна життєва позиція мовної особистості - автора літературного щоденника - бурхливо прагне виявити себе у слові. Така мовна особистість є незвичайним творцем мови, вона тонко й розлого відчуває всі іiі барви, знає й шанує іï закони, володіє високим рівнем мовної, комунікативної, емоційної, етнокультурної компетенції. У щоденниковому дискурсі таку (ㄷ. С. Є. Ігнатьєва, 2013. 
зразкову, еталонну, сильну особистість відносимо до мовної особистості елітарного типу. На думку мовознавця Т. І. Панько поняття «інтелігентне мовлення» становить мовлення людини iз «відчуттям» мови, направленістю на самовдосконалення, внутрішнім прагненням до краси, контактністю 3 іншими людьми свого середовища $[1$, с.9]. ЕМО можна назвати продуцентів літературних щоденникових текстів. Вони мають досить високий ступінь лінгвістичної та комунікативної компетенції, прагнуть до вільного самовираження й самовдосконалення, яке поєднується 3 вільним, автоматичним здійсненням різнобічної мовної діяльності.

Визначення параметрів ЕМО, сформованих у межах щоденникового дискурсу, сприяє не тільки поглибленню теоретикометодологічної бази теорії мовної особистості, але й створює підгрунтя для розвитку прагматичного напрямку моделювання зразкової мовної особистості діариста, що є важливим для сучасної щоденникової комунікації.

3 огляду на проведений аналіз можна констатувати, що синтаксичні параметри мовлення $є$ індивідуалізованим показником мовної особистості. Мовна особистість елітарного типу формується засобами емоційно-психічного та інтелектуального сприйняття мовцем граматичної природи певних синтаксичних конструкцій. Граматико-семантична особливість організації певних синтаксичних одиниць перманентно існує в природі синтаксичної конструкції, відносно однаково впливає на інтелектуально-психічний облік носіїв мови, формує сферу пріоритетних конструкцій, які вживає мовець продуцент щоденникового тексту.

\section{Література}

1. Балли Ш. Общая лингвистика и вопросы французкого языка / Ш. Балли. - М. : Изд-во иностр. лит., 1955. - 416 с.

2. Воля О. Щоденник. Сорок років. 1969-2009 / О. Воля. - К. : Аконіт, 2011. - 1208 с.

3. Гончар О. Т. Щоденники : у 3-х т. : Т. 1 (1943-1967) / О. Т. Гончар ; упор., підгот. текстів, ілюстр. матеріалу В. Д. Гончар ; худож. оформ. М. С. Пшінки. - [2-ге вид., вир. і доп.]. - К. : Веселка, 2008. -455 с.

4. Гончар О. Т. Щоденники : у 3-х т. : Т. 2 (1968-1983) / О. Т. Гончар ; упор., підгот. текстів, ілюстр. матеріалу В. Д. Гончар ; худож. оформ. М. С. Пшінки. - [2-ге вид., вир. і доп.]. - К. : Веселка, 2008. - 607 с.

5. Гончар О. Т. Щоденники : у 3-х т. : Т. 3 (1984-1995) / О. Т. Гончар ; упор., підгот. текстів, ілюстр. матеріалу В. Д.Гончар ; худож. оформ. М. С. Пшінки. - [2-ге вид., вир. і доп.]. - К. : Веселка, 2008. - 646 с.

6. Довженко О. Вибрані твори / О. Довженко ; упор. текстів та передм. І. Л. Михайлина. - Харків : Веста : Видавництво «Ранок», 2003. - 320 с.

7. Любченко А. П. Вертеп (повість). Оповідання. Щоденник / А. П. Любченко ; 
упор., авт. післямов. В. А. Любченко ; авт. передм., комент., приміт. І. Л. Михайлин. Х. : Основа, 2005. - 464 с.

8. Максименко С. Д. Розвиток особистості: проблема психологічних механізмів / С. Д. Максименко // Педагогічна і психологічна науки в Україні. - Т. 3. Психологія, вікова фізіологія та дефектологія. - Київ, 2007.

9. Руднев А. Г. Синтаксис современного русского языка : [учеб. пособ. для ун-тов и пед. ин-тов] / А. Г. Руднев. - М. : Высшая школа, 1963. - 364 с.

10. Сербенська О. А. Викладання української мови в контексті сучасних вимог / О. А. Сербенська // Педагогіка і психологія професійної освіти. - 1998. - С. 120-125.

Стаття надійшла до редакції 25.11.2013 р. 